\title{
Functional Mannose-Binding Lectin Levels in Patients with End-Stage Renal Disease on Maintenance Hemodialysis
}

\author{
Atsushi Satomura ${ }^{a}$ Takayuki Fujita $^{b}$ Mitsuru Yanai ${ }^{c}$ Kazunari Kumasaka ${ }^{a}$ \\ Yuki Uehara $^{\mathrm{a}, \mathrm{d}}$ Kazuyoshi Okada ${ }^{\mathrm{b}}$ Yoshinobu Fuke ${ }^{\mathrm{b}}$ Tomohiro Nakayama $^{\mathrm{a}}$ \\ ${ }^{a}$ Division of Laboratory Medicine, Department of Pathology and Microbiology, and Divisions of \\ ${ }^{b}$ Nephrology, Hypertension and Endocrinology and ' ${ }^{C}$ General Internal Medicine, Department of Medicine, \\ Nihon University School of Medicine, and dDepartment of Infection Control Science/General Medicine, \\ Faculty of Medicine, Juntendo University, Tokyo, Japan
}

\section{Key Words}

Chronic renal failure $\cdot$ Diabetes $\cdot$ ELISA $\cdot$ End-stage renal disease $\cdot$ Hemodialysis - Infection - Innate immunity •

Mannose-binding lectin

\begin{abstract}
Background: Innate immunity is generally impaired in chronic renal failure (CRF). Mannose-binding lectin (MBL) has an important role in first-line host defense against pathogens via the lectin pathway. We recently reported that functional MBL was significantly lower in CRF patients than in healthy subjects. In this study, we aimed to determine whether functional MBL would be improved following hemodialysis (HD) therapy. Methods: This study included 22 patients with end-stage renal disease (ESRD) on maintenance HD. Functional MBL was measured every 6 months for 1 year after HD using an enzyme-linked immunosorbent assay. Results: Median serum functional MBL levels of ESRD patients were significantly higher after 6 and 12 months than at the start of HD therapy $(p<0.05$ and $p<0.01$, respectively). Furthermore, median functional MBL levels at 12 months were significantly higher than those at 6 months
\end{abstract}

$(p<0.05)$. Conclusions: We found significant increases in serum functional MBL levels in patients on HD. Our results indicated that HD tailored to remove uremic toxins could improve functional MBL levels in these patients.

Copyright $\odot 2012$ S. Karger AG, Basel

\section{Introduction}

The responses of the human immune system to pathogens are coordinated by both innate and acquired immune functions. Impairments in innate immunity (e.g. reduced polymorphonuclear leukocyte chemotaxis, phagocytosis, and bactericidal activity) as well as acquired immunity (reduced T-cell function) are hallmarks in patients with chronic renal failure (CRF) [1-6]. Therefore, end-stage renal disease (ESRD) is associated with an increased incidence of infections, which is a major cause of death in the dialysis population $[1,7,8]$. Dysfunction of cellular immunity may actually be responsible for the high incidence of infections and cardiovascular diseases in those patients [1]. Recently, it was reported that reduced expression of Toll-like receptors in uremic patients

\section{KARGER}

Fax +41613061234

E-Mail karger@karger.ch

www.karger.com (c) 2012 S. Karger AG, Basel

$1662-811 X / 12 / 0043-0293 \$ 38.00 / 0$

Accessible online at:

www.karger.com/jin
Dr. Atsushi Satomura

Division of Laboratory Medicine, Department of Pathology and Microbiology Nihon University School of Medicine, 30-1, Oyaguchi-kamimachi, Itabashi-ku Tokyo 173-8610 (Japan)

Tel.+81 33972 8111,E-Mail satomura.atsushi@nihon-u.ac.jp 
was due to impairment in innate immunity [9], and that uremia impaired the function of monocyte-derived dendritic cells as well as monocytes in vitro. It was suggested that hemodialysis (HD) therapy to remove uremic toxins might improve immune function in vitro [10].

Mannose-binding lectin (MBL) is a serum lectin secreted by the liver. MBL, in addition to acting as an opsonin, has an important role in innate immune defense against invading microorganisms by activating a complement cascade via the lectin pathway [11-15]. MBL is also a positive acute-phase protein [16, 17]. Moreover, we reported that MBL function in innate immunity in CRF patients was decreased compared with controls. Also, the functional/oligomer MBL ratio was significantly lower in CRF patients than in healthy subjects [18]. Evidence has been increasing in support of the association between $\mathrm{MBL}$ and renal disease. The involvement of MBL in glomeruli was reflected by a poor renal prognosis, e.g. more severe renal disease in cases of IgA nephropathy (Roos et al. [19]) and in patients with antinuclear antibody-negative Pauci-immune crescentic glomerulonephritis (Xing et al. [20]). In dialysis patients (Ibernon et al. [21]), low pretransplant levels of MBL were associated with chronic inflammation, new-onset diabetes mellitus after transplantation, and infection. Nevertheless, there are only a few reports on the role of MBL in CRF patients.

Though it is generally understood that immunocompetence declines in CRF patients, the clinical course of functional MBL after HD therapy remains to be clarified in ESRD patients. In this study, we aimed to determine whether functional MBL levels would be improved following HD therapy for uremia and acidosis.

\section{Patients and Methods}

\section{Patients}

The study group comprised 22 patients with ESRD, who had not received dialysis therapy but were to be treated with maintenance HD therapy. Table 1 summarizes the clinical characteristics of the patients treated with HD. HD patients were clinically stable and did not present acute cardiovascular, cerebrovascular, infectious, or other active disease during the 3 months prior to study entry. HD patients with hepatitis B or $\mathrm{C}$ virus and patients with liver cirrhosis without hepatitis virus infection were excluded from this study.

The ESRD patients were started on HD therapy at the Itabashi Hospital of the Nihon University School of Medicine, Tokyo, Japan, and were receiving maintenance HD therapy at satellite hospitals of the Nihon University School of Medicine. Follow-up of the HD patients lasted 1 year. A cellulose triacetate filter was used in the dialyzer for all patients. Functional and oligomer MBL concentrations in the sera of the HD patients were measured three times: at the start of HD therapy, and after 6 and 12 months. Their blood samples were collected from January 2003 to December 2004. There were 16 males and 6 females. Diabetes was present in 11 , and 11 were without diabetes; 3 patients had chronic glomerulonephritis, 3 hypertension, 1 gout, 1 polycystic kidney disease and 1 had renal cell carcinoma; in the remainder, the origin of kidney disease was unknown. Mean age was $59 \pm 14$ years. The mean and median levels of serum components were as follows: blood urea nitrogen (BUN), $101.4 \pm 30.8 \mathrm{mg} / \mathrm{dl}$; serum creatinine, $9.64 \pm 3.32 \mathrm{mg} / \mathrm{dl} ; \mathrm{pH}, 7.374$ (range 7.288-7.399); $\mathrm{HCO}_{3}^{-}$, $19.6 \pm 5.5 \mathrm{mmol} / \mathrm{l}$; hemoglobin, $8.4 \pm 1.8 \mathrm{~g} / \mathrm{dl}$; white blood cell

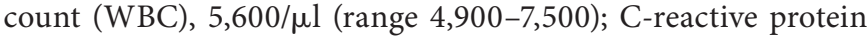
(CRP), $0.20 \mathrm{mg} / \mathrm{dl}$ (range $0.10-0.65)$; estimated glomerular filtration rate (eGFR), $5.5 \pm 2.2 \mathrm{ml} / \mathrm{min}$; albumin, $3.4 \pm 0.4 \mathrm{mg} / \mathrm{dl}$; total cholesterol, $167 \pm 42 \mathrm{mg} / \mathrm{dl}$, and high-density-lipoprotein (HDL) cholesterol, $38 \pm 12 \mathrm{mg} / \mathrm{dl}$. Informed consent was obtained from all patients before entering the study. Serum samples were stored at $-80^{\circ} \mathrm{C}$ until analysis.

Reporting of the study conforms to the STROBE statement along with references to STROBE and the broader EQUATOR guidelines [22].

\section{Measurement of Serum Levels of $M B L$}

Functional and oligomer MBL levels in the sera were assessed using commercial enzyme-linked immunosorbent assay (ELISA) kits.

Functional MBL concentration was measured with the human MBL lectin assay ELISA kit (Hycult Biotech, The Netherlands). Briefly, microtiter plates were coated with mannan, and serum samples and standards were diluted 1:5 with MBL-binding buffer and incubated in the wells. During incubation, the mannan captured the functional MBL. Unbound MBL in the sample was removed by washing. Biotinylated antibody to human MBL was added to the wells to bind to the mannan-bound MBL. Streptavidin-peroxidase conjugate was applied to the wells, reacting specifically with biotinylated antibody. After addition of tetramethylbenzidine to the wells, color developed proportionally to the amount of MBL present in the samples. The enzyme reaction was stopped by the addition of citric acid in the wells and the absorbance at $450 \mathrm{~nm}$ was measured in a spectrophotometer.

Oligomer MBL concentration was measured with the MBL oligomer ELISA kit (BioProto Diagnostics, Denmark). Briefly, microtiter plates were coated with a monoclonal anti-MBL antibody against the MBL carbohydrate-binding domain, and serum samples and standards diluted 1:200 with sample diluent buffer were incubated in the wells. During incubation, the monoclonal anti-MBL antibody captured the oligomer MBL in sera. Next, plates were incubated with biotinylated anti-human MBL antibody. Subsequent steps involving streptavidin-peroxidase conjugate through color development were the same as for functional MBL.

\section{Statistical Analysis}

Normally distributed values were expressed as the mean \pm $\mathrm{SD}$, and non-normally distributed values as the median value and range (25th-75th percentiles). To assess the significance of differences between groups, the two-tailed paired t test for normally distributed values with equal variances, Welch's test for normally distributed values with unequal variances, and the Mann-Whitney $U$ test for non-normally distributed values were performed. 
Table 1. Clinical characteristics of the ESRD patients $(n=22)$

\begin{tabular}{lc}
\hline Gender, males/females & $16 / 6$ \\
Age, years & $59 \pm 14$ \\
Diabetes mellitus, \% & 50 \\
BUN, mg/dl & $101.1 \pm 30.8$ \\
Serum creatinine, mg/dl & $9.64 \pm 3.32$ \\
$\mathrm{pH}$ & $7.374(7.288-7.399)$ \\
$\mathrm{HCO}_{3}^{-}, \mathrm{mmol} / \mathrm{l}$ & $19.6 \pm 5.5$ \\
$\mathrm{Hemoglobin}_{\mathrm{g}}$ g/dl & $8.4 \pm 1.8$ \\
$\mathrm{WBC}, \mathrm{n} / \mu \mathrm{l}$ & $5,600(4,900-7,500)$ \\
$\mathrm{CRP}, \mathrm{mg} / \mathrm{dl}$ & $0.20(0.10-0.65)$ \\
eGFR, ml/min & $5.5 \pm 2.2$ \\
Albumin, g/dl & $3.4 \pm 0.4$ \\
Total cholesterol, mg/dl & $167 \pm 42$ \\
HDL cholesterol, mg/dl & $38 \pm 12$
\end{tabular}

Data are expressed as means \pm SD or medians (ranges: 25 th75th percentiles). For SI conversion, multiply by 10 for hemoglobin and albumin levels (g/dl), by 88 for creatinine levels (mmol/l), and by 0.0259 for cholesterol levels $(\mathrm{mmol} / \mathrm{l})$.
As the data of each group consisted of normally distributed values with equal variances, the differences among groups were assessed using analysis of variance. If a statistically significant difference was detected, each group was assessed using the Tukey-Kramer test. As the data of each group also consisted of non-normally distributed values, the differences among groups were assessed using the Kruskal-Wallis test, and in case of a statistically significant difference, each group was assessed using the Steel-Dwass test. The correlation of various parameters was evaluated by Pearson's correlation analysis for normally distributed values, and by Spearman's correlation analysis for non-normally distributed values. All statistical analyses were performed using JMP 7.0.2 (SAS Inc., USA) on a Macintosh computer.

Functional and oligomer MBL levels were non-normally distributed values. Therefore, it was difficult to predetermine a sample size. There were 62 ESRD patients who were started on HD therapy from January 2003 to December 2003. Forty of these patients were excluded for the following reasons: acute cardiovascular (3); cerebrovascular (2); infectious (20), or other active disease (8); hepatitis B (2); hepatitis C (3), and liver cirrhosis (2). Thus, 22 patients met the inclusion criteria of this study with no dropout.

\section{Results}

\section{Serum Levels of Functional MBL}

Median levels of functional MBL in the sera of $22 \mathrm{HD}$ patients at the start of regular HD therapy, and after 6 and 12 months were 543 (range: 276-600), 657 (range: 383728 ) and $846 \mathrm{ng} / \mathrm{ml}$ (range: 356-911 $\mathrm{ng} / \mathrm{ml}$ ), respectively. The levels at $6(\mathrm{p}<0.05)$ and 12 months $(\mathrm{p}<0.01)$ were

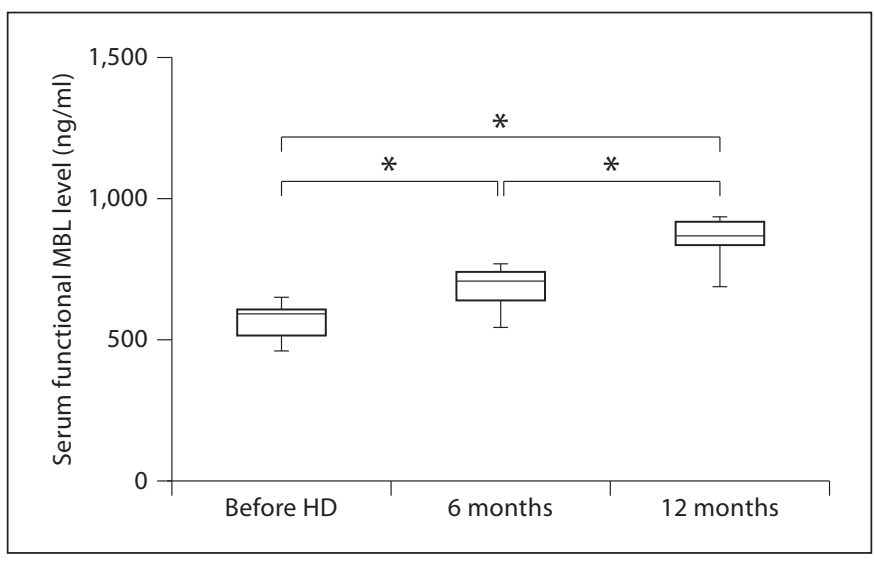

Fig. 1. Functional MBL levels in ESRD patients on HD except for the patients with non-measurable values of functional MBL ( $\mathrm{n}=$ 17): $591 \mathrm{ng} / \mathrm{ml}$ (range: $514-607 \mathrm{ng} / \mathrm{ml}$ ) at the start of regular HD therapy; $707 \mathrm{ng} / \mathrm{ml}$ (range: $630-744 \mathrm{ng} / \mathrm{ml}$ ) after 6 months, and $868 \mathrm{ng} / \mathrm{ml}$ (range: $836-919 \mathrm{ng} / \mathrm{ml}$ ) after 12 months of HD. ${ }^{*} \mathrm{p}<$ 0.01 .

higher than at the start of HD therapy. The 12-month level was also higher $(\mathrm{p}<0.05)$ than the 6 -month level (table 2). The $5 \mathrm{HD}$ patients whose functional MBL could not be measured were labeled as the absolutely low functional MBL group, and the other $17 \mathrm{HD}$ patients were labeled as the relatively low functional MBL group. Excluding the 5 $\mathrm{HD}$ patients from analysis, the median functional MBL levels (17 HD patients) at the start of HD, after 6 and 12 months were: 591 (range: 514-607), 707 (range: 630-744) and $868 \mathrm{ng} / \mathrm{ml}$ (range: $836-919 \mathrm{ng} / \mathrm{ml}$ ), respectively. The levels at $6(p<0.01)$ and 12 months $(p<0.01)$ were higher than at the start of HD therapy. The 12-month level was also higher $(\mathrm{p}<0.01)$ than the 6 -month level (fig. 1$)$. The overall pattern was the same regardless of the inclusion of the $5 \mathrm{HD}$ patients in the absolutely low functional MBL group for analysis. The $22 \mathrm{HD}$ patients were further classified into non-diabetic $(\mathrm{n}=11)$ and diabetic $(\mathrm{n}=11)$ groups, and their serum levels of functional MBL were compared. For the non-diabetic patients, the levels at the start of the regular HD therapy, and after 6 and 12 months were 540 (range: 0-609), 651 (range: 0-718) and $853 \mathrm{ng} /$ $\mathrm{ml}$ (range: $0-911 \mathrm{ng} / \mathrm{ml}$ ), respectively. For the diabetic patients, the levels were 591 (range: 368-598), 707 (range: 511-735) and $839 \mathrm{ng} / \mathrm{ml}$ (range: $474-926 \mathrm{ng} / \mathrm{ml}$ ), respectively. No differences were detected in the levels of functional MBL between the non-diabetic and diabetic groups at each of the three sampling times. 
Table 2. Functional and oligomer MBL and CRP levels in the sera of the ESRD patients on HD $(n=22)$

\begin{tabular}{|c|c|c|c|c|c|c|c|c|c|c|}
\hline \multirow{2}{*}{$\begin{array}{l}\mathrm{Pa}- \\
\text { tient } \\
\text { No. }\end{array}$} & \multirow[t]{2}{*}{ Renal disease } & \multicolumn{3}{|c|}{ Functional MBL, ng/ml } & \multicolumn{3}{|c|}{ Oligomer MBL, ng/ml } & \multicolumn{3}{|c|}{$\mathrm{CRP}, \mathrm{mg} / \mathrm{dl}$} \\
\hline & & $\begin{array}{l}\text { before } \\
\text { HD }\end{array}$ & $\begin{array}{l}6 \\
\text { months }\end{array}$ & $\begin{array}{l}12 \\
\text { months }\end{array}$ & $\begin{array}{l}\text { before } \\
\text { HD }\end{array}$ & $\begin{array}{l}6 \\
\text { months }\end{array}$ & $\begin{array}{l}12 \\
\text { months }\end{array}$ & $\begin{array}{l}\text { before } \\
\text { HD }\end{array}$ & $\begin{array}{l}6 \\
\text { months }\end{array}$ & $\begin{array}{l}12 \\
\text { months }\end{array}$ \\
\hline 1 & hypertension & 517 & 658 & 911 & 1,812 & 2,334 & 3,232 & 0.15 & 0.10 & 0.17 \\
\hline 2 & diabetes & 458 & 656 & 654 & 2,270 & 2,519 & 4,168 & 0.13 & 0.10 & 0.10 \\
\hline 3 & chronic glomerulonephritis & 635 & 771 & 912 & 7,999 & 14,433 & 9,963 & 0.10 & 0.10 & 0.10 \\
\hline 4 & diabetes & ND & ND & ND & 328 & 366 & 660 & 0.74 & 0.10 & 0.10 \\
\hline 5 & unknown & 511 & 718 & 853 & 2,172 & 2,694 & 4,674 & 0.59 & 0.10 & 0.10 \\
\hline 6 & diabetes & 368 & 541 & 839 & 13,671 & 11,487 & 10,712 & 0.10 & 0.43 & 0.10 \\
\hline 7 & diabetes & 591 & 724 & 926 & 11,888 & 9,536 & 7,883 & 0.25 & 0.10 & 0.10 \\
\hline 8 & chronic glomerulonephritis & ND & ND & ND & 481 & 649 & 693 & 0.12 & 0.22 & 0.10 \\
\hline 9 & diabetes & 598 & 752 & 935 & 13,373 & 14,459 & 14,562 & 0.29 & 0.10 & 0.10 \\
\hline 10 & renal cell carcinoma & ND & ND & ND & 523 & 718 & 710 & 0.26 & 0.10 & 0.10 \\
\hline 11 & diabetes & 591 & 707 & 839 & 1,693 & 3,269 & 4,004 & 0.10 & 0.10 & 0.10 \\
\hline 12 & chronic glomerulonephritis & 545 & 677 & 868 & 7,353 & 8,076 & 8,657 & 0.10 & 0.10 & 0.10 \\
\hline 13 & diabetes & 605 & 735 & 869 & 5,505 & 11,668 & 13,877 & 0.94 & 0.60 & 0.10 \\
\hline 14 & hypertension & 609 & 651 & 826 & 10,893 & 13,231 & 11,087 & 0.79 & 0.99 & 0.16 \\
\hline 15 & diabetes & ND & ND & ND & 286 & 436 & 632 & 0.64 & 0.10 & 0.10 \\
\hline 16 & diabetes & 689 & 762 & 977 & 5,128 & 5,381 & 7,179 & 0.10 & 0.70 & 0.10 \\
\hline 17 & hypertension & ND & ND & ND & 438 & 559 & 747 & 0.85 & 0.60 & 0.10 \\
\hline 18 & diabetes & 592 & 725 & 900 & 12,579 & 14,975 & 9,950 & 0.10 & 0.10 & 0.10 \\
\hline 19 & diabetes & 465 & 511 & 474 & 3,410 & 5,093 & 6,359 & 0.23 & 0.10 & 0.10 \\
\hline 20 & gout & 559 & 608 & 833 & 12,508 & 9,355 & 13,445 & 0.10 & 0.10 & 0.10 \\
\hline 21 & polycystic kidney & 540 & 553 & 860 & 6,145 & 8,771 & 11,345 & 0.68 & 0.36 & 0.50 \\
\hline 22 & unknown & 655 & 942 & 934 & 5,615 & 6,900 & 8,107 & 0.17 & 0.10 & 0.10 \\
\hline \multicolumn{2}{|c|}{ Median } & 543 & 657 & $846^{*, * *}$ & 5,317 & 6,141 & 7,531 & 0.20 & 0.10 & $0.10^{* *}$ \\
\hline \multicolumn{2}{|c|}{ Range $^{a}$} & $276-600^{*}$ & $383-728$ & $356-911$ & $1,401-11,142$ & $1,930-11,532$ & $2,611-10,806$ & $010-0.65$ & $0.10-0.38$ & $(0.10-0.10)$ \\
\hline
\end{tabular}

Data are expressed as medians ( ${ }^{\mathrm{a}}$ ranges: $25 \mathrm{th}-75 \mathrm{th}$ percentiles). ${ }^{*} \mathrm{p}<0.05 \mathrm{vs}$. at 6 months; ${ }^{* *} \mathrm{p}<0.01 \mathrm{vs}$. before HD. ND $=$ Not detected.

Serum Levels of Oligomer MBL

Median levels of oligomer MBL in the sera of $22 \mathrm{HD}$ patients at the start of regular HD therapy, and after 6 and 12 months were 5,317 (range: 1,401-11,142), 6,141 (range: $1,930-11,532$ ) and 7,531 ng/ml (range: 2,611-10,806 ng/ $\mathrm{ml}$ ), respectively (table 2). The differences among these three sampling times were not significant. As with functional MBL, the $22 \mathrm{HD}$ patients were also classified into a relatively low functional MBL group and an absolutely low functional MBL group, and their serum levels of oligomer MBL were compared. For the relatively low functional MBL group (17 HD patients), the levels at the start of regular HD therapy, and after 6 and at 12 months were 6,145 (range: 2,840-12,198), 8,771 (range: 4,181$12,450)$ and $8,657 \mathrm{ng} / \mathrm{ml}$ (range: $5,517-11,216 \mathrm{ng} / \mathrm{ml}$ ), respectively. The differences among these three sampling times were not significant. For the absolutely low functional MBL group (5 HD patients), the levels were 438 (range: 307-502), 559 (range: 401-684) and $693 \mathrm{ng} / \mathrm{ml}$ (range: $646-729 \mathrm{ng} / \mathrm{ml}$ ), respectively. The level at 12 months $(\mathrm{p}<0.05)$ was higher than at the start of HD therapy. Moreover, there were significant differences between the relatively and absolutely low functional MBL groups at each of the three sampling times $(\mathrm{p}<0.01)$. Furthermore, the $22 \mathrm{HD}$ patients were classified into nondiabetic and diabetic groups, and their levels of oligomer MBL were compared. For the non-diabetic patients, the levels at the start of regular HD therapy, and after 6 and 12 months were 5,615 (range: 523-7,999), 6,900 (range: $718-9,355)$ and $8,107 \mathrm{ng} / \mathrm{ml}$ (range: $747-11,087 \mathrm{ng} / \mathrm{ml}$ ), respectively. For the diabetic patients, the levels were 5,128 (range: 1,693-12,579), 5,381 (range: 2,519-11,668) and 7,179 $\mathrm{ng} / \mathrm{ml}$ (range: 4,004-10,712 $\mathrm{ng} / \mathrm{ml}$ ), respectively. There were no differences in the serum levels of oligomer MBL between the non-diabetic and diabetic groups at each of the three sampling times.

\section{Serum Levels of CRP}

Median levels of CRP in the sera of $22 \mathrm{HD}$ patients at the start of regular HD therapy, and after 6 and 12 months 
Table 3. Correlations of serum values for CRP with functional and oligomer MBL for each sampling time in ESRD patients on HD therapy

\begin{tabular}{|c|c|c|c|c|c|c|}
\hline & \multicolumn{2}{|l|}{ Before HD } & \multicolumn{2}{|l|}{6 months } & \multicolumn{2}{|l|}{12 months } \\
\hline & $\begin{array}{l}\text { correlation } \\
\text { coefficient }\end{array}$ & $\mathrm{p}$ value & $\begin{array}{l}\text { correlation } \\
\text { coefficient }\end{array}$ & $\mathrm{p}$ value & $\begin{array}{l}\text { correlation } \\
\text { coefficient }\end{array}$ & $\mathrm{p}$ value \\
\hline Functional MBL and CRP & -0.239 & 0.274 & -0.107 & 0.623 & 0.038 & 0.704 \\
\hline Oligomer MBL and CRP & -0.352 & 0.107 & 0.127 & 0.560 & 0.179 & 0.413 \\
\hline
\end{tabular}

Table 4. Clinical characteristics of ESRD patients with $(\mathrm{n}=11)$ and without diabetes $(\mathrm{n}=11)$

\begin{tabular}{lccc}
\hline & No diabetes & Diabetes & p value \\
\hline Absolutely low functional MBL, $\mathrm{n}$ & 3 & 2 & 0.610 \\
Gender, males/females & $7 / 4$ & $9 / 2$ & 0.335 \\
Age, years & $55 \pm 17$ & $63 \pm 9$ & 0.182 \\
BUN, mg/dl & $112.4 \pm 22.3$ & $89.8 \pm 34.9$ & 0.021 \\
Serum creatinine, mg/dl & $10.6 \pm 2.6$ & $8.7 \pm 3.8$ & 0.180 \\
$\mathrm{pH}$ & $7.375(7.328-7.397)$ & $7.365(7.171-7.404)$ & 0.554 \\
$\mathrm{HCO}_{3}^{-}, \mathrm{mmol} / \mathrm{l}$ & $19.9 \pm 5.4$ & $19.3 \pm 5.9$ & 0.801 \\
$\mathrm{Hemoglobin}_{\text {g }} / \mathrm{dl}$ & $8.7 \pm 0.7$ & $8.0 \pm 1.2$ & 0.375 \\
WBC, / $\mathrm{ll}$ & $6,500(4,900-9,300)$ & $5,100(4,600-7,500)$ & 0.237 \\
$\mathrm{CRP}, \mathrm{mg} / \mathrm{dl}$ & $0.17(0.10-0.68)$ & $0.23(0.10-0.66)$ & 0.840 \\
eGFR, ml/min & $4.6 \pm 1.6$ & $6.3 \pm 2.5$ & 0.080 \\
Albumin, g/dl & $3.5 \pm 0.5$ & $3.3 \pm 0.4$ & 0.290 \\
Total cholesterol, mg/dl & $167 \pm 43$ & $166 \pm 43$ & 0.965 \\
HDL cholesterol, mg/dl & $37 \pm 13$ & $39 \pm 11$ & 0.704 \\
\hline
\end{tabular}

Data are expressed as means \pm SD or medians (ranges: 25 th-75th percentiles). For SI conversion, multiply by 10 for hemoglobin and albumin levels $(\mathrm{g} / \mathrm{dl})$, by 88 for creatinine levels $(\mathrm{mmol} / \mathrm{l})$, and by 0.0259 for cholesterol levels ( $\mathrm{mmol} / \mathrm{l})$.

were 0.20 (range: $0.10-0.65), 0.10$ (range: $0.10-0.38$ ) and $0.10 \mathrm{mg} / \mathrm{dl}$ (range: $0.10-0.10 \mathrm{mg} / \mathrm{dl}$ ), respectively (table 2 ). Among these three sampling times, significance was detected only for the difference between CRP levels at the start and after 12 months of HD ( $<<0.01)$. Furthermore, for the non-diabetic patients, the levels at the start of regular HD therapy, and after 6 and 12 months were 0.17 (range: $0.10-0.68$ ), 0.10 (range: $0.10-0.36$ ) and $0.10 \mathrm{mg} / \mathrm{dl}$ (range: $0.10-0.16 \mathrm{mg} / \mathrm{dl}$ ), respectively. The differences among these three sampling times were not significant. For the diabetic patients, the levels were 0.23 (range: 0.10 0.64 ), 0.17 (range: $0.10-0.43$ ) and $0.10 \mathrm{mg} / \mathrm{dl}$ (range: 0.10 $0.10 \mathrm{mg} / \mathrm{dl}$ ), respectively. The level after 12 months was lower than that at the start of HD therapy in the diabetic group $(\mathrm{p}<0.01)$. However, there was no significant difference between the non-diabetic and diabetic groups.

\section{Serum Levels of MBLs}

In the 22 ESRD patients, there were no differences in the functional and oligomer MBL levels with respect to gender and diabetes mellitus, and there were no correlations between the functional and oligomer MBL levels for the following parameters: age, BUN, serum creatinine, $\mathrm{pH}, \mathrm{HCO}_{3}^{-}$, hemoglobin, WBC, CRP, eGFR, albumin, total cholesterol and HDL cholesterol. Examining the associations of serum functional MBL levels and clinical variables, a significant correlation was noted only for $\mathrm{HCO}_{3}^{-}$(correlation coefficient $=0.508, \mathrm{p}<0.05$ ) when 5 patients with non-measurable values of functional MBL were excluded from analysis. There were no correlations between the functional and oligomer MBL levels, and for $\mathrm{CRP}$ at the start of regular HD therapy, and after 6 and at 12 months (table 3 ). 
Table 5. Correlations of serum values for functional and oligomer MBL in the 22 ESRD patients

\begin{tabular}{lll}
\hline Oligomer MBL & Correlation coefficient & p value \\
\hline Before HD & 0.607 & 0.005 \\
At 6 months & 0.652 & 0.003 \\
At 12 months & 0.588 & 0.007 \\
\hline
\end{tabular}

\section{Levels in Non-Diabetic and Diabetic Groups}

There were no differences between the non-diabetic and diabetic groups for the following parameters except for BUN: numbers of patients with non-measurable values of serum functional MBL, gender, age, serum creatinine, $\mathrm{pH}, \mathrm{HCO}_{3}^{-}$, hemoglobin, WBC, CRP, eGFR, albumin, total cholesterol and HDL cholesterol (table 4). The BUN level was significantly lower in the diabetic patients than in the non-diabetic patients $(\mathrm{p}<0.05)$.

\section{Functional $M B L$ versus Oligomer $M B L$}

Examining the associations of functional and oligomer MBL levels, significant correlations were noted at the start of regular HD therapy, and after 6 and 12 months, respectively (correlation coefficient $=0.607,0.652$ and $0.588 ; \mathrm{p}=0.005, \mathrm{p}=0.003$ and $\mathrm{p}=0.007$, respectively; table 5).

\section{Discussion}

In this study, we found elevated levels of functional MBL in ESRD patients on HD therapy. The impairment in the immune system in ESRD patients involved both acquired and innate immunity. In our previous report, the functional/oligomer MBL ratio was significantly reduced in CRF patients compared to healthy subjects. Functional MBL levels were also significantly lower in CRF patients than in healthy subjects [18]. Finally, the lower levels of functional MBL just before HD therapy were significantly ameliorated by HD therapy.

The serum and plasma of patients on maintenance HD contains uremic toxins with low and high molecular weight, which had been implicated in the dysfunction of the innate immune system; particularly polymorphonuclear leukocytes and mononuclear phagocytes would result in reduced chemotaxis and oxidative activity in response to phagocytosis [23-26]. Polymorphonuclear leukocyte function improved in CRF patients following the commencement of peritoneal dialysis, which suggested that the soluble uremic toxins were removed by dialysis [27]. Functional MBL levels were significantly higher at 6 and 12 months than at the start of HD therapy. Also, at 12 months functional MBL level was significantly higher than at 6 months. Although the patients might be hypervolemic at the induction of HD therapy, at discharge they would be in the normovolemic state. As our patients were not hypervolemic 6 and 12 months after the start of HD therapy, it was important that the functional MBL levels at 12 months were significantly higher than at 6 months. However, it is conceivable that the functional MBL levels might either plateau or decrease at longer follow-ups because the median level of $130 \mathrm{HD}$ patients followed up for $\geq 2$ years was $814 \mathrm{ng} / \mathrm{ml}$ (range: $706-912 \mathrm{ng} / \mathrm{ml}$ ), which is close to the 12-month level of $846 \mathrm{ng} / \mathrm{ml}$ (range: 356-911 $\mathrm{ng} / \mathrm{ml})[18]$.

In this study, it was assumed that there would be decreases in functional MBL in ESRD patients when compared with healthy subjects, whose serum level of functional MBL was $1,321 \mathrm{ng} / \mathrm{ml}$ (range: $1,188-1,515 \mathrm{ng} / \mathrm{ml}$ ) [18]. The functional MBL level of patients subjected to HD for 1 year was about 45-65\% higher than the level of healthy subjects. Generally, a patient with a low functional MBL level might be associated with unusual and severe infections [28]. Infectious disease was the first leading cause of death in newly diagnosed patients started on dialysis in 2008, and the second cause of death in 2008 among the entire dialysis population in Japan [8]. Infectious disease has always ranked high as a cause of death in patients undergoing dialysis. Thus, the decline in functional MBL, a component of innate immunity, may be one of the underlying causes. Moreover, low functional MBL $(<500 \mathrm{ng} / \mathrm{ml})$ might be a significant risk factor for the development of cytomegalovirus infection in kidney transplant recipients [29]. However, pancreas and kidney transplant patients with low functional MBL ( $<400 \mathrm{ng}$ / $\mathrm{ml}$ ) had significantly longer transplant survival than those who had levels $>400 \mathrm{ng} / \mathrm{ml}$ [30]. Due to the low number of renal transplant cases in Japan, we could not study the possible association between transplant survival and MBL.

There were no differences in oligomer MBL levels among the three sampling times, although the levels showed gradual elevations during the clinical course from the start of HD therapy. Median levels of oligomer MBL of $130 \mathrm{HD}$ patients, who had been on regular HD therapy for at least 2 years, were $8,500 \mathrm{ng} / \mathrm{ml}$ (range: $5,278-12,355 \mathrm{ng} / \mathrm{ml}$ ) in our previous study [18]. It is possible that the levels might increase at longer follow-ups, although it would be expected to plateau with time. In our 
previous report on $\mathrm{HD}$ patients, oligomer MBL levels were shown to be significantly higher than in CRF patients who had not received dialysis therapy [31]. Oligomer MBL levels in ESRD patients were elevated, confirming the results of our previous studies [18, 31]. HD patients were susceptible to many inflammatory reactions. As a result, oligomer MBL levels in ESRD patients were likely to be elevated. In this study, we had changed the method for measurement from that used in previous studies. The oligomer MBL levels were measured with a commercial ELISA kit (MBL oligomer ELISA kit; BioProto Diagnostics). Previously, the serum oligomer MBL levels were measured by an ELISA using polyclonal rabbit IgG and a monoclonal antibody directed against MBL (3E7) [31-34]. Both primary and secondary antibodies were different using the two ELISA methods. The level of oligomer MBL was 1,753 ng/ml (range: 1,445-1,960 ng/ $\mathrm{ml}$ ) for healthy subjects in this study. On the other hand, the level of oligomer MBL was 1,897 ng/ml (range: 1,630$2,254 \mathrm{ng} / \mathrm{ml}$ ) for the same healthy subjects in the previous study $[18,31]$. There was a strong correlation between the two methods (correlation coefficient $=0.789 ; \mathrm{p}<0.001$ ). Therefore, it suggests that there are no differences in the two methods of measuring oligomer MBL levels.

In this study, the functional MBL level correlated with the oligomer MBL level at all sampling points, a feature which was not observed previously. However, inasmuch as oligomer MBL is characteristic of positive acute-phase proteins like CRP, functional and oligomer MBL levels showed no correlations with CRP levels. Interestingly, in a report by Akbari et al. [35], the correlation between MBL and CRP levels was not significant in HD patients, which concurred with the correlation between oligomer MBL and high-sensitivity CRP levels found in our previous study [34]. MBL and CRP are both primarily synthesized in the liver, and levels of proinflammatory cytokines such as interleukin-6, interleukin-1 and tumor necrosis factor- $\alpha$ are generally affected. However, oligomer MBL might not be characteristic of positive acute-phase proteins like CRP in HD patients. Therefore, we would recommend the measurement and evaluation of serum functional MBL, oligomer MBL, and CRP in ESRD patients.

The immune system of patients with diabetes mellitus was generally impaired. Since there were no differences in the levels of functional and/or oligomer MBL, as well as in each of the clinical parameters except for BUN levels between the non-diabetic and diabetic patients, it appears that diabetes hardly influenced the level of functional and/or oligomer MBL in our ESRD patients. There was no difference in the number of ESRD patients with nonmeasurable values of functional MBL between non-diabetic and diabetic groups. In our study, non-diabetic and diabetic groups constituted 27 and $18 \%$, respectively, of ESRD patients with non-measurable values of functional MBL. Tsutsumi et al. [36] reported that $32 \%$ of the healthy Japanese volunteers had a codon 54 mutation, whereas codon 52 and 57 mutations were absent. ESRD patients with non-measurable values of functional MBL showed no particular tendency to progress to HD therapy.

Serum functional MBL mediates inflammation by opsonizing pathogenic microorganisms and activating the complement system. Thus, elevation in the functional MBL concentration might reduce mortality due to infectious disease among dialysis patients. Although many previous reports have discussed the relationship between $\mathrm{MBL}$ and different types of diseases, it is necessary to measure functional MBL for the evaluation of innate immunity.

\section{Acknowledgment}

We thank Yuki Wada for her technical assistance.

\section{Disclosure Statement}

No conflict of interest declared.

\section{References}

1 Kato S, Chmielewski M, Honda H, PecoitsFilho R, Matsuo S, Yuzawa Y, Tranaeus A, Stenvinkel P, Lindholm B: Aspects of immune dysfunction in end-stage renal disease. Clin J Am Soc Nephrol 2008;3:15261533.

Functional MBL in ESRD Patients
J Innate Immun 2012;4:293-300 
6 Goldblum SE, Reed WP: Host defenses and immunologic alterations associated with chronic hemodialysis. Ann Intern Med 1980; 93:597-613.

7 Sarnak MJ, Jaber BL: Mortality caused by sepsis in patients with end-stage renal disease compared with the general population. Kidney Int 2000;58:1758-1764.

8 Nakai S, Suzuki K, Masakane I, Wada A, Itami N, Ogata S, Kimata N, Shigematsu T, Shinoda T, Syouji T, Taniguchi M, Tsuchida K, Nakamoto H, Nishi S, Nishi H, Hashimoto S, Hasegawa T, Hanafusa N, Hamano T, Fujii N, Marubayashi S, Morita O, Yamagata K, Wakai K, Watanabe Y, Iseki K, Tsubakihara $\mathrm{Y}$ : Overview of regular dialysis treatment in Japan (as of 31 December 2008). Ther Apher Dial 2010;14:505-540.

-9 Ando M, Shibuya A, Tsuchiya K, Akiba T, Nitta K: Reduced expression of Toll-like receptor 4 contributes to impaired cytokine response of monocytes in uremic patients. Kidney Int 2006;70:358-362.

$\checkmark 10$ Lim WH, Kireta S, Leedham E, Russ GR, Coates PT: Uremia impairs monocyte and monocyte-derived dendritic cell function in hemodialysis patients. Kidney Int 2007;72: 1138-1148.

-11 Kawasaki N, Kawasaki T, Yamashina I: Isolation and characterization of a mannan-binding protein from human serum. J Biochem 1983;94:937-947.

-12 Wild J, Robinson D, Winchester B: Isolation of mannose-binding proteins from human and rat liver. Biochem J 1983;210:167-174.

13 Summerfield JA, Taylor ME: Mannose-binding proteins in human serum: identification of mannose-specific immunoglobulins and a calcium-dependent lectin, of broader carbohydrate specificity, secreted by hepatocytes. Biochim Biophys Acta 1986;883:197206.

14 Matsushita M: The lectin pathway of the complement system. Microbiol Immunol 1996;40:887-893.

-15 Neth O, Jack DL, Dodds AW, Holzel H, Klein NJ, Turner MW: Mannose-binding lectin binds to a range of clinically relevant microorganisms and promotes complement deposition. Infect Immun 2000;68:688-693.

16 Ezekowitz RA, Day LE, Herman GA: A human mannose-binding protein is an acutephase reactant that shares sequence homology with other vertebrate lectins. J Exp Med 1988;167:1034-1046.
17 Thiel S, Holmskov U, Hviid L, Laursen SB, Jensenius JC: The concentration of the Ctype lectin, mannan-binding protein, in human plasma increases during an acute phase response. Clin Exp Immunol 1992;90:31-35.

18 Satomura A, Fujita T, Fuke Y, Yanai M, Kumasaka K, Takayama E, Hamada H, Maruyama T, Nakayama T: Relationship between oligomer and functional serum mannose-binding lectin in chronic renal failure. Eur J Clin Invest 2010;40:865-873.

19 Roos A, Rastaldi MP, Calvaresi N, Oortwijn BD, Schlagwein N, van Gijlswijk-Janssen DJ, Stahl GL, Matsushita M, Fujita T, van Kooten C, Daha MR: Glomerular activation of the lectin pathway of complement in IgA nephropathy is associated with more severe renal disease. J Am Soc Nephrol 2006;17:17241734.

20 Xing GQ, Chen M, Liu G, Zheng X, E J, Zhao $\mathrm{MH}$ : Differential deposition of C4d and MBL in glomeruli of patients with ANCAnegative pauci-immune crescentic glomerulonephritis. J Clin Immunol 2010;30:144156.

21 Ibernon M, Moreso F, Moreno JM, Bestard O, Cruzado JM, Grinyo JM, Ricart W, Fernandez-Real JM, Seron D: Low serum mannose-binding lectin as a risk factor for new onset diabetes mellitus after renal transplantation. Transplantation 2009;88:272-278.

22 Simera I, Moher D, Hoey J, Schulz KF, Altman DG: A catalogue of reporting guidelines for health research. Eur J Clin Invest 2010;40: 35-53.

23 Masuda M, Komiyama Y, Murakami T, Murata K: Decrease of polymorphonuclear leukocyte membrane fluidity in uremic patients on hemodialysis. Nephron 1990;54:36-41.

24 Vanholder R, De Smet R, Jacobs V, Van Landschoot N, Waterloos MA, Vogeleere P, Ringoir S: Uraemic toxic retention solutes depress polymorphonuclear response to phagocytosis. Nephrol Dial Transplant 1994; 9:1271-1278.

25 Jorstad S, Viken KE: Inhibitory effects of plasma from uraemic patients on human mononuclear phagocytes cultured in vitro. Acta Pathol Microbiol Scand C 1977;85:169177.

26 Jorstad S, Kvernes S: Uraemic toxins of high molecular weight inhibiting human mononuclear phagocytes cultured in vitro. Acta Pathol Microbiol Scand C 1978;86C:221226.

-27 Porter CJ, Burden RP, Morgan AG, Daniels I, Fletcher J: Impaired polymorphonuclear neutrophil function in end-stage renal failure and its correction by continuous ambulatory peritoneal dialysis. Nephron 1995;71: 133-137.
28 Summerfield JA, Ryder S, Sumiya M, Thursz M, Gorchein A, Monteil MA, Turner MW: Mannose binding protein gene mutations associated with unusual and severe infections in adults. Lancet 1995;345:886-889.

-29 Manuel O, Pascual M, Trendelenburg M, Meylan PR: Association between mannosebinding lectin deficiency and cytomegalovirus infection after kidney transplantation. Transplantation 2007;83:359-362.

30 Berger SP, Roos A, Mallat MJ, Schaapherder AF, Doxiadis II, van Kooten C, Dekker FW, Daha MR, de Fijter JW: Low pretransplantation mannose-binding lectin levels predict superior patient and graft survival after simultaneous pancreas-kidney transplantation. J Am Soc Nephrol 2007; 18:2416-2422.

- 31 Satomura A, Endo M, Ohi H, Sudo S, Ohsawa I, Fujita T, Matsushita M: Significant elevations in serum mannose-binding lectin levels in patients with chronic renal failure. Nephron 2002;92:702-704.

- 32 Terai I, Kobayashi K, Fujita T, Hagiwara K: Human serum mannose binding protein (MBP): development of an enzyme-linked immunosorbent assay (ELISA) and determination of levels in serum from 1085 normal Japanese and in some body fluids. Biochem Med Metab Biol 1993;50:111-119.

33 Satomura A, Fujita T, Matsumoto K: Mannose-binding lectin level and polymorphism in patients on long-term peritoneal dialysis - level of serum mannose binding lectin with end-stage renal disease. Nephrol Dial Transplant 2006;21:1729-1730, author reply $1730-1731$.

34 Satomura A, Endo M, Fujita T, Ohi H, Ohsawa I, Fuke Y, Matsumoto K, Sudo S, Matsushita M: Serum mannose-binding lectin levels in maintenance hemodialysis patients: impact on all-cause mortality. Nephron Clin Pract 2006;102:c93-c99.

35 Akbari R, Mireskandari M, Alizadeh-Navaei R, Ghods A: Measurement of serum levels of mannose-binding lectin in hemodialysis patients: a comparison with healthy individuals. Iran J Kidney Dis 2011;5:255-259.

36 Tsutsumi A, Sasaki K, Wakamiya N, Ichikawa K, Atsumi T, Ohtani K, Suzuki Y, Koike T, Sumida T: Mannose-binding lectin gene: polymorphisms in Japanese patients with systemic lupus erythematosus, rheumatoid arthritis and Sjögren's syndrome. Genes Immun 2001;2:99-104. 